\title{
Mobile Teaching: Merging Smart Phones, Cloud, and Desktop to Achieve Content-specific Instruction in a Generic Environment
}

\section{Dr. Larry Burton, North Carolina A\&T University (Tech)}

Dr. Burton received his BS, MS, and Ph.D. in electrical engineering from Duke University. He has 25 years executive international management experience in technology-based businesses, and holds ten patents in microwave and optical communications, video switching, and broadband infrastructure. His current research is focused on high availability / high reliability enterprise computing.

\section{Dr. Robert Cobb Jr., North Carolina A\&T State University \\ Dr. Ibraheem A. Kateeb, North Carolina A\&T State University}

Dr. Ibraheem Kateeb is the section chair of Central NC section and a Senior Member of IEEE with over 25 years of experience in academia and industry. He received his Ph.D. from NCA\&TSU. He is currently at NCA\&TSU as Assistant Professor of Computer Systems Technology Department. His current research is on power and green energy, and control/robotics. In the last two years, he published more than 27 journal and conference papers and has many projects and grants in Power, Renewable Energy and Smart Grid related issues. Dr. Kateeb was recognized as the recipient of Academic Excellent Award from CARTS International 2012 (ECIA Electronic Components Industry Association).

\section{Dr. Li-Shiang Tsay, North Carolina A \& T State University}

Li-Shiang Tsay earned her Ph.D. degree in information technology from the University of North Carolina at Charlotte and is an Assistant Professor in the Department of Computer Systems Technology at NCA\&TSU. Her research aims to augment people's ability to deliver high performing solutions to maximize their data assets. To this end, she conducts research that spans the areas of Data Mining, Multimedia Databases, Intelligent Web Search, Complexity Adaptive Systems, and Rough Sets. The results of her research are widely published in several referred journals, book chapters, and conference proceedings and were presented at several international conferences. Dr. Tsay edited books for Springer and InderScience publishers. She is a member of the Editorial Board of an international journal in data mining. She was Program Chair of several international conferences. She has served and is currently serving as a member of the Program Committee of several international conferences. Dr. Tsay is honored to serve as a member of the Honorary Chair and Advisory Boards for several international conferences.

\section{Dr. Cameron Seay, North Carolina A\&T State University}

Cameron Seay is an Assistant Professor in the Department of Computer Systems Technology at North Carolina A\&T State University. He holds a doctorate in educational psychology and advanced degrees in business, computer information systems and economics.

\section{Dr. Tony E. Graham I, Department of Built Environment}

Tony E. Graham, D. Eng., Assoc. AIA, is an Associate Professor - Navy Research Fellow in the Department of Built Environment - Construction Management program - School of Technology at North Carolina A\&T State University, Greensboro where he specializes in sustainable construction, building information model (BIM) and geographic information systems (GIS). He received his Doctorate of Engineering and Masters of Architecture from Morgan State University and BS in Architectural Engineering from North Carolina A\&T State University. With over 30 years of combined professional and academic experience, Dr. Graham has served as principal investigator on research projects addressing GIS technology and education, including projects on a) the development of a GIS carbon footprint model and b) anti terrorism and airborne contaminants, which recently were presented at the ESRI International GIS Users Conferences. From 2006 to 2013, Dr. Graham has presented his research at state, regional and international conferences. Dr. Graham has received several awards including National Black Herstory Task Force 
Recognition, several North Carolina Sustainable Building Design Competition Awards, Environmental Design + Construction Sustainable Design Award, American Society for Quality Competition Award, and a Faculty of the Year Award. He has developed undergraduate architectural curriculum and Masters of Architecture programs. He has also developed undergraduate curriculum in construction management using BIM technology. Currently he is working on developing GIS and BIM certification programs at the graduate level.

Dr. Chafic BouSaba, NC A\&T SU, CST Dept. 


\title{
Mobile Teaching: Merging Smart Phones, Cloud, and Desktop to Achieve Content- specific Instruction in a Generic Environment
}

\begin{abstract}
Many educational institutions face a similar problem today: the necessity to reorganize teaching and lab space to improve facility utilization. North Carolina Agricultural and Technical Statue University (NCA\&T) made the difficult decision to eliminate dedicated labs and classrooms for content-specific instruction. Labs and classrooms previously equipped with private networks and custom operating systems were replaced with a single large classroom equipped with thin-client Windows-based computers.

Student demand for Linux instruction has grown eight-fold in four years at NCA\&T. In fall 2012, seats were limited to 60 students in two 30-student sections, and more students were involuntarily dropped. This begs the question, "How do large classes of students learn the intricate details of the Linux operating system in a Windows-based classroom with no lab?" The obvious answer is cloud-based Linux images, but cloud access alone is not a learning environment. The authors implemented a mobile virtual environment which included a new textbook, new learning aides, and an immersive hands-on regimen. Before and after metric-based learning outcome assessment demonstrate no adverse impact on the quality of education resulting from the elimination of content-specific classrooms and labs.
\end{abstract}

\section{Introduction}

This paper provides quantitative results of funding cutbacks on technology teaching at NCA\&T University. At NCA\&T, a "perfect storm” of greatly increased class size, reduced instructional space, and replacement of technology-specific equipment with generic infrastructure came together in the summer of 2012. The obvious expectation of the authors is that achievement of learning outcomes and over-all student satisfaction would decrease. The authors focused on objective measurement of this "perfect storm" in an introductory Linux class. Historical objective learning outcome data and student satisfaction survey results for this course were available from the previous four years from the same instructor. Surprisingly, results of the fall 2012 semester showed that learning outcomes and overall student satisfaction with the course were little changed from the historical trend. Though the results of this study were specific to a single technology topic, readers readily can extrapolate the results to other technology programs. The authors believe the continued educational success is a result of the aggressive, proactive change in the course delivery method detailed in this paper.

\section{Background}

Until fall 2012, the Introduction to Linux course was primarily a senior-year elective. Registration grew from six students in 2007 to 75 students in 2012. The growth in registration was a result of several drivers. The over-all student course satisfaction surveys consistently ranked the course as superior, and students recommended the course to other students. Linux 
knowledge became increasingly desirable in the information technology workplace, and some graduates reported the course as instrumental in obtaining employment. By fall 2011, class size had grown to 29 students.

Reductions in instructional funding for the University mandated greater efficiency in instructional delivery. The course shifted from an every semester offering to an every academic year offering, and the course was not offered in spring 2012. Some students graduated without taking the elective, and others had to wait until fall 2012.

The faculty recognized the increased importance of Linux in the workplace as well as the synergistic impact of Linux instruction with the high performance computing and mainframe operations tracks. All incoming freshmen in fall 2012 have the Linux course as a first-semester requirement. The department halted fall 2012 registration at 75 students, and then involuntarily removed elective students to bring the total enrollment to 59 students. No students dropped the course during the semester.

Reduced instructional funding also demanded increased space utilization efficiency. This challenge was exacerbated by the establishment of a STEM early high school in the same building and the subsequent loss of classroom space. Prior to fall 2012, Linux instruction took place in a classroom configured for seated instruction and equipped with six dedicated Linux workstations. The authors' research equipment supplemented the instructional equipment to provide an isolated local area network, enterprise infrastructure, and additional workstations. In June 2012, the administration made a decision to re-purpose the instructional space into a thirtyseat generic classroom with back-to-back course booking. No other instructional space was available, and all equipment used for Linux instruction was moved to storage.

Reduced instructional funding hit another blow in late July 2012. Original plans for the repurposed classroom called for thirty workstations with the option of dual booting operating systems. Unfortunately, funding constraints forced a change in plans to equip the room with thinclient stations. All thirty stations were served by a single server running thirty images of a Microsoft Windows 7 operating system ${ }^{1}$. The system became operational a few weeks after the start of fall 2012 classes. Back-to-back room scheduling gave no time for IT staff to service the inevitable station failures resulting from technology failures and students attempting to re-boot and re-arrange cabling of the thin clients.

The fall 2012 semester of Linux instruction began in a classroom with no computer access at all, and with best hopes of having thin clients running a sluggish Windows 7 image with no persistent storage. Enrollment was capped at 59 students, half of whom were freshmen taking their first technology course. Fortunately, the authors had a plan.

\section{Methodology}

The authors have worked together as a team for several years on various projects focused on delivering technology education courses to under-served communities ${ }^{2}$. The projects' course experience base includes architectural drawing, electronics, data mining, networking, and operating systems. The authors have experimented with traditional content management systems, 
custom web applications, private clouds, and hybrid instruction ${ }^{3,4}$ Other researchers have reported on efforts to integrate smart mobile devices into instruction ${ }^{5,6}$. There is a saying, "Forthcoming events cast their shadows." The authors began work on an alternative course delivery in June 2012.

The guiding principle is "Linux learning, anywhere, anytime." This concept eliminates the traditional notion of a classroom or lab or any standardized delivery platform. Students should be able to use any available communication device to access course resources and complete learning exercises. Resources should be available 24/7 from anywhere. One critical factor is the recognition that students of the digital age cannot remember a time without instant access. Students of the digital age are used to multi-tasking. For example, a student is likely to check a Facebook page update, then read a paragraph of a reading assignment, check a sports score, and then answer a homework problem. And, from a student's point of view, all this can take place while socializing in the student union.

The implementation began with a new e-book format textbook designed to present topics and tasks in five-minute sections targeted toward mobile device access. The text was available at no charge to the students, and supplemented the traditional printed textbook. This approach was enthusiastically received by students accustomed to instant access, self-paced learning, and instant gratification. Students perceive reading assignments almost as a game to be completed on their smart phone while walking to class or connected to the wi-fi hotspot. Each short lesson is followed by individual hands-on exercises as illustrated in Figure 1, "Hands-on Exercise”.

Figure 1: Hands-on Exercise

Hands-on: pushd
Adds a directory to the top of the directory stack
The pushd command saves the current working path on the stack
and changes the working directory to that specified in the command
line.
Enter the command:
[ janealinserv ] $\$$ pushd /tmp
pushd will automatically invoke the dirs command after changing to
the new directory, so a list of all remembered directories will be
displayed, followed by a new command prompt. For example, if you
invoked the pushd command from your home directory, which is
represented by the tilda ( $~$ ) character, you will see output similar to
the following.
/ tmp $\sim$ [ janealin se rv tmp] $\$$

Students used Secure Shell (SSH), for example, the free "ConnectBot” Android application ${ }^{7}$, or a comparable i-Phone application, to access multiple physical and cloud-based Linux servers 
directly from their mobile device. Other applications, such as the Firefox web browser, allowed access to web-based services.

In 1956, Bloom's Taxonomy identified learning through repetition as a fundamental, low-level learning method, a claim many authors, including Kausar and others, have since documented to facilitate assimilation of the brief reading and hands-on exercises ${ }^{8}$. Students could access a server and view flashcards geared to each topic, as illustrated in Figure 2, "Flashcard example", allowing students to reinforce their learning through directed repetition.

Figure 2: Flashcard Example

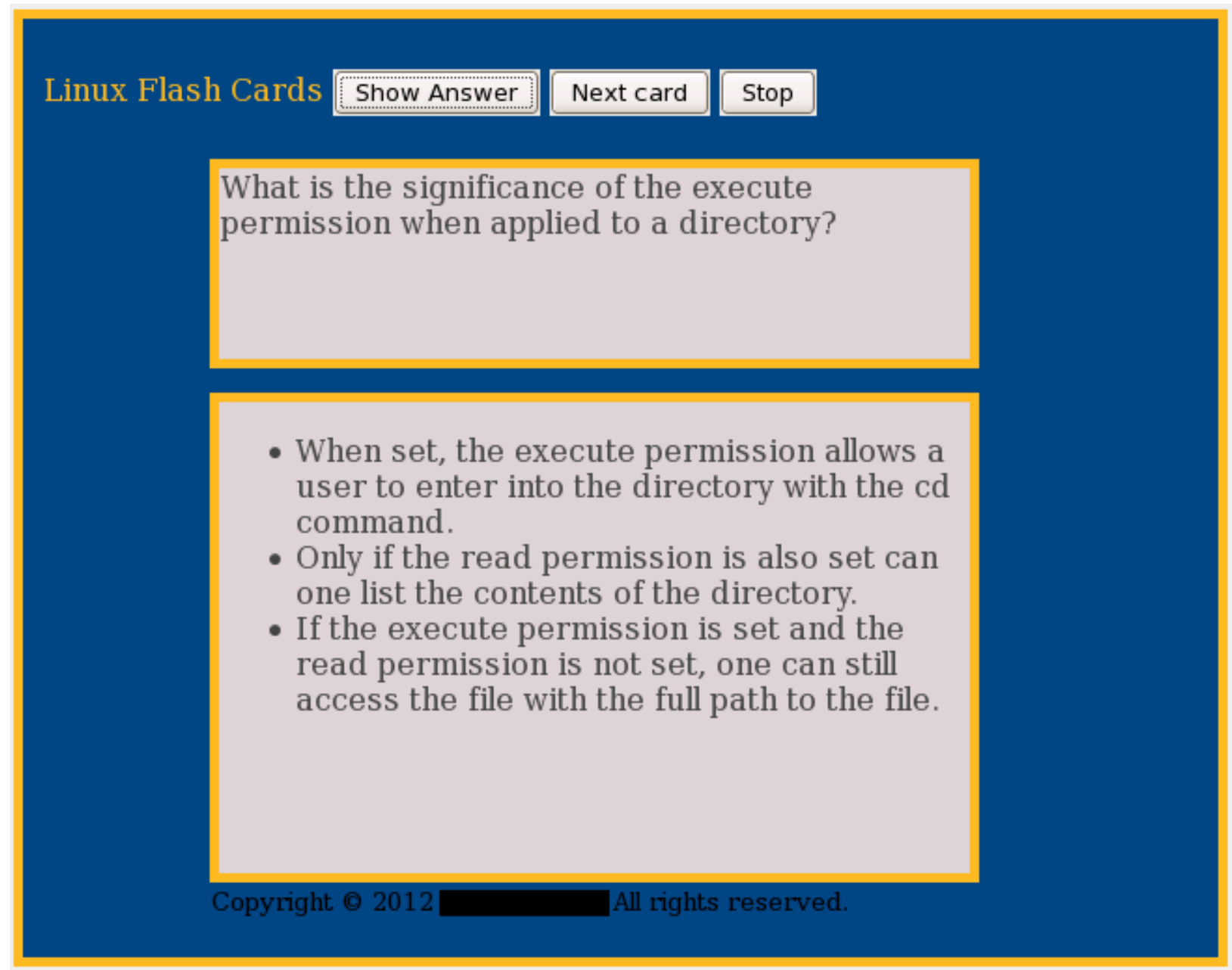

In the classroom, mini-lectures expand upon the reading, and selected five-minute, hands-on practice sessions reinforce the mini-lectures and accommodate limited attention spans. Students use personal wi-fi connected smart phones, tablets, laptops, and the desktop Windows thin clients in the classroom. Key to the desktop usage is the Firefox web browser with FireSSH ${ }^{9}$, Figure 3, "FireSSH Plug-in", and epub-reader ${ }^{10}$ add-ons, Figure 4, "E-pub reader".

Students use multiple windows to have a side-by-side textbook and Linux command line interface available, as well as access to the content management system. The command-line 
interface to a common group of servers engages students in an electronic collaborative environment that emulates the professional global enterprise IT environment. The seamless, mobile-oriented environment provides students with 24/7 course access from almost any device or operating system. Importantly, all resources are accessed using standard web (port 80) access, thus avoiding firewall interference.

Figure 3: FireSSH Plug-in

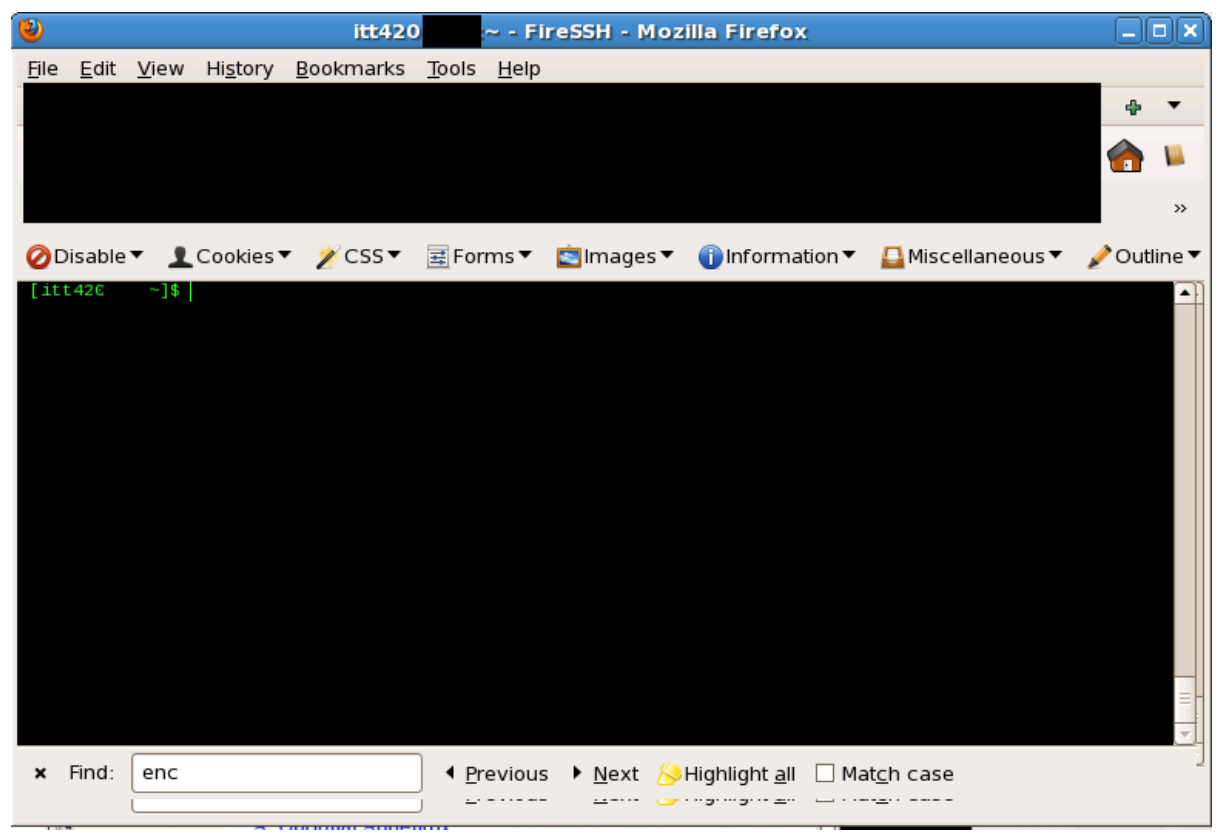

Figure 4: e-pub Reader

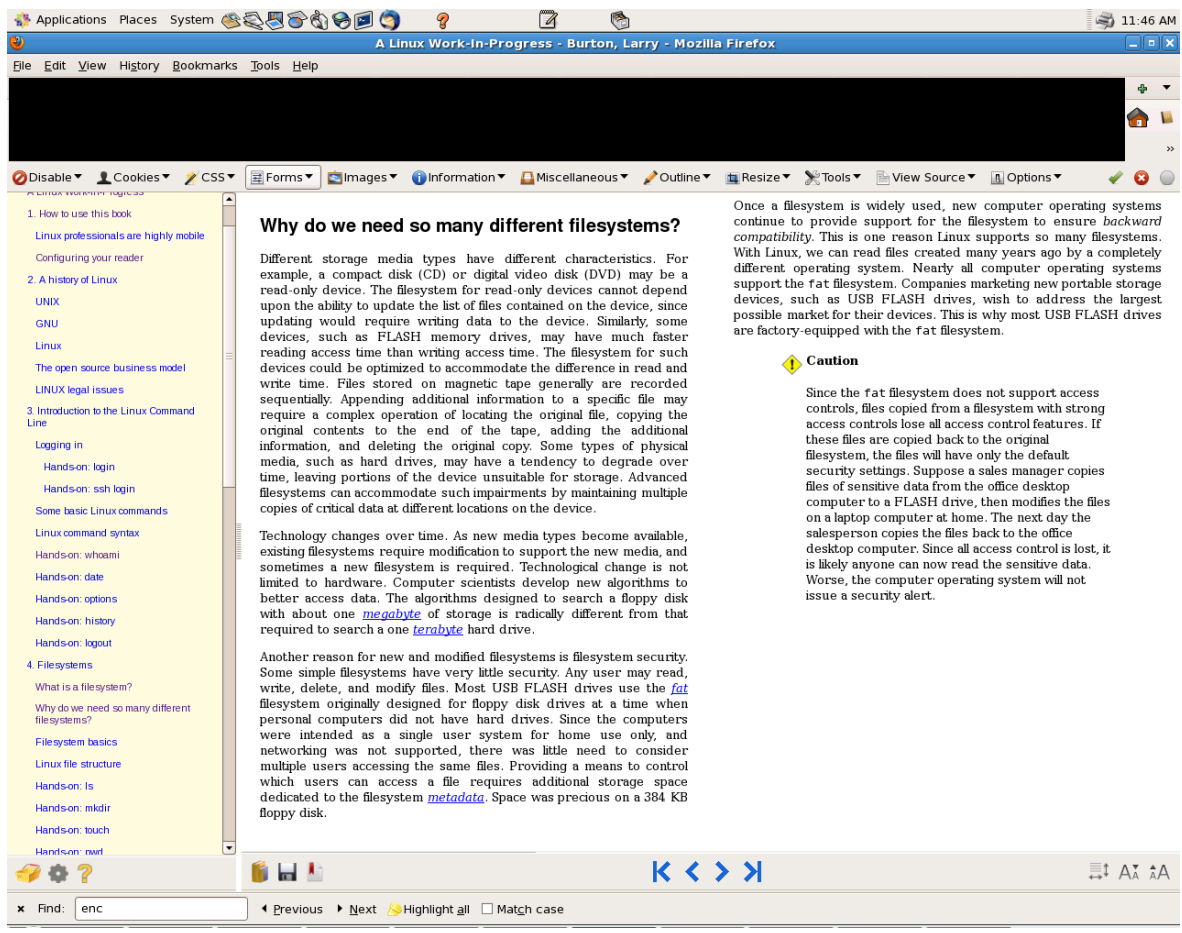


Written and oral communication is a vital part of an IT education. Students were required to prepare a research report and post the report on a class wiki. This process emulates participation in conferences such as ASEE. Students were also required to present their findings. Presentations were peer-reviewed using a custom on-line rubric and database as illustrated in Figure 5, "Peer Review Form”.

Figure 5: Peer Review Form

\section{ITT 420 Presentations, Fall 2012 \\ Peer Evaluation Form}

Presentation assignments are assessed on a 28-point scale according to the following rubric. Presentations must be suitable for technical conferences.

Any presentation containing plagiarized content will receive a total grade of 0 points and the student will be subject to the provisions of the Student Handbook.

For this executive briefing format, no graphics are allowed. All students will receive four points for graphics.

\begin{tabular}{|c|c|c|c|c|c|}
\hline Reviewer & Presenter & & & & \\
\hline & 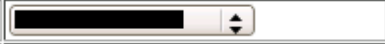 & & & & \\
\hline $\begin{array}{c}\text { Point/value } \\
\text { Category }\end{array}$ & 1 & 2 & 3 & 4 & Total \\
\hline Assignment & $\begin{array}{l}\text { Student does not cover the subject as } \\
\text { directed. }\end{array}$ & $\begin{array}{l}\text { Student covers a minimal } \\
\text { amount of required material. }\end{array}$ & $\begin{array}{l}\text { Student covers an average } \\
\text { amount of material required. }\end{array}$ & $\begin{array}{l}\text { Student follows directions as } \\
\text { given and covers the subject } \\
\text { thoroughly. }\end{array}$ & $1 \leqslant$ \\
\hline Organization & $\begin{array}{l}\text { Audience cannot understand } \\
\text { presentation because there is no } \\
\text { logic sequence of information. }\end{array}$ & $\begin{array}{l}\text { Audience has difficulty } \\
\text { following presentation } \\
\text { because student jumps } \\
\text { around. }\end{array}$ & $\begin{array}{l}\text { Student presents information } \\
\text { in logical sequence which } \\
\text { audience can follow. }\end{array}$ & $\begin{array}{l}\text { Student presents information in } \\
\text { logical, interesting sequence } \\
\text { which audience can follow. }\end{array}$ & $1 \div$ \\
\hline $\begin{array}{l}\text { Subject } \\
\text { Knowledge }\end{array}$ & $\begin{array}{l}\text { Student does not have grasp of } \\
\text { information; student cannot answer } \\
\text { any questions about the subject. }\end{array}$ & $\begin{array}{l}\text { Student is uncomfortable with } \\
\text { information and is able to } \\
\text { answer only very basic } \\
\text { questions. }\end{array}$ & $\begin{array}{l}\text { Student is at ease with and } \\
\text { answers all questions, but } \\
\text { does not elaborate. }\end{array}$ & $\begin{array}{l}\text { Student demonstrates full } \\
\text { kmowledge by answering all } \\
\text { class question and explains } \\
\text { elaborately. }\end{array}$ & $1 \leqslant$ \\
\hline Graphics & $\begin{array}{l}\text { Student uses superfluous graphics or } \\
\text { no graphics. }\end{array}$ & $\begin{array}{l}\text { Student occasionally uses } \\
\text { graphics that rarely support } \\
\text { text and presentation. }\end{array}$ & $\begin{array}{l}\text { Student's graphics relate to } \\
\text { the text and presentation. }\end{array}$ & $\begin{array}{l}\text { Student's graphics explain and } \\
\text { reinforce screen text and } \\
\text { presentation. }\end{array}$ & $4 \div$ \\
\hline Mechanics & $\begin{array}{l}\text { Student's presentation has four or } \\
\text { more spelling and/or grammatical } \\
\text { errors. }\end{array}$ & $\begin{array}{l}\text { Student's presentation has } \\
\text { three spelling and/or } \\
\text { grammatical errors. }\end{array}$ & $\begin{array}{l}\text { Student's presentation has } \\
\text { one or two spelling and/or } \\
\text { grammatical errors. }\end{array}$ & $\begin{array}{l}\text { Student's presentation has no } \\
\text { spelling and/or grammatical } \\
\text { errors. }\end{array}$ & $1 \leqslant$ \\
\hline Eye Contact & $\begin{array}{l}\text { Student reads all of report with no } \\
\text { eye contact. }\end{array}$ & $\begin{array}{l}\text { Student occasionally uses eye } \\
\text { contact, but reads most of } \\
\text { report. }\end{array}$ & $\begin{array}{l}\text { Student maintains eye contact } \\
\text { most of the time, but } \\
\text { frequently uses notes. }\end{array}$ & $\begin{array}{l}\text { Student maintains eye contact } \\
\text { with audience, seldom using } \\
\text { notes. }\end{array}$ & $1 \leqslant$ \\
\hline Elocution & $\begin{array}{l}\text { Student mumbles incorrectly } \\
\text { pronounces terms, and speaks too } \\
\text { quietly for the audience to hear. }\end{array}$ & \begin{tabular}{|l|} 
Student's voice is low. Student \\
incorrectly pronounces terms. \\
Audience has difficultly \\
hearing presentation.
\end{tabular} & $\begin{array}{l}\text { Student's voice is clear and } \\
\text { student pronounces most } \\
\text { words correctly. Most of } \\
\text { audience can hear the } \\
\text { presentation. }\end{array}$ & $\begin{array}{l}\text { Student uses a clear voice and } \\
\text { projects so that all of audience } \\
\text { can hear. Student uses correct } \\
\text { and precise pronunciation. }\end{array}$ & $1 \leqslant$ \\
\hline \multicolumn{6}{|l|}{ Submit } \\
\hline Find: & enc & - Next High & ight all $\square$ Matchn case & & \\
\hline
\end{tabular}

Once again, the presentation and peer-review process emulates a conference presentation. Having an automated data collection system is essential for peer reviews of large numbers of students. Over 1100 individual reviews were collected in fall 2012 from 59 students. The communication assignments are designed to function both in a synchronous classroom setting and an asynchronous on-line setting where students upload videos of their presentations to the class wiki. The instructor used a similar on-line rubric to assess student papers. 


\section{Results}

Fifty-nine students completed the fall 2012 course. Students were divided into two sections. Section 1 had thirty students, two of whom were freshmen, and most were juniors or seniors. Section 2 had 29 students, all but one were freshmen, and the remaining student was a sophomore. In prior years, all students were upperclassmen, so fall 2012 results may be compared with prior years, as well as comparing the performance of freshmen versus upperclassmen in the same environment.

Two metrics were used to measure the efficacy of the 2012 course versus prior years. The first metric is the student satisfaction survey. Results are shown in Figure 6, "Satisfaction Survey Results". The second, course ABET outcomes, are available for two prior years. An example is shown in Figure 7, "Learning Outcomes”. Student responses were tightly grouped. The maximum standard deviation for any survey response in any year was 0.80 with about $90 \%$ of students typically responding to the survey.

\section{Figure 6: Satisfaction Survey Results}

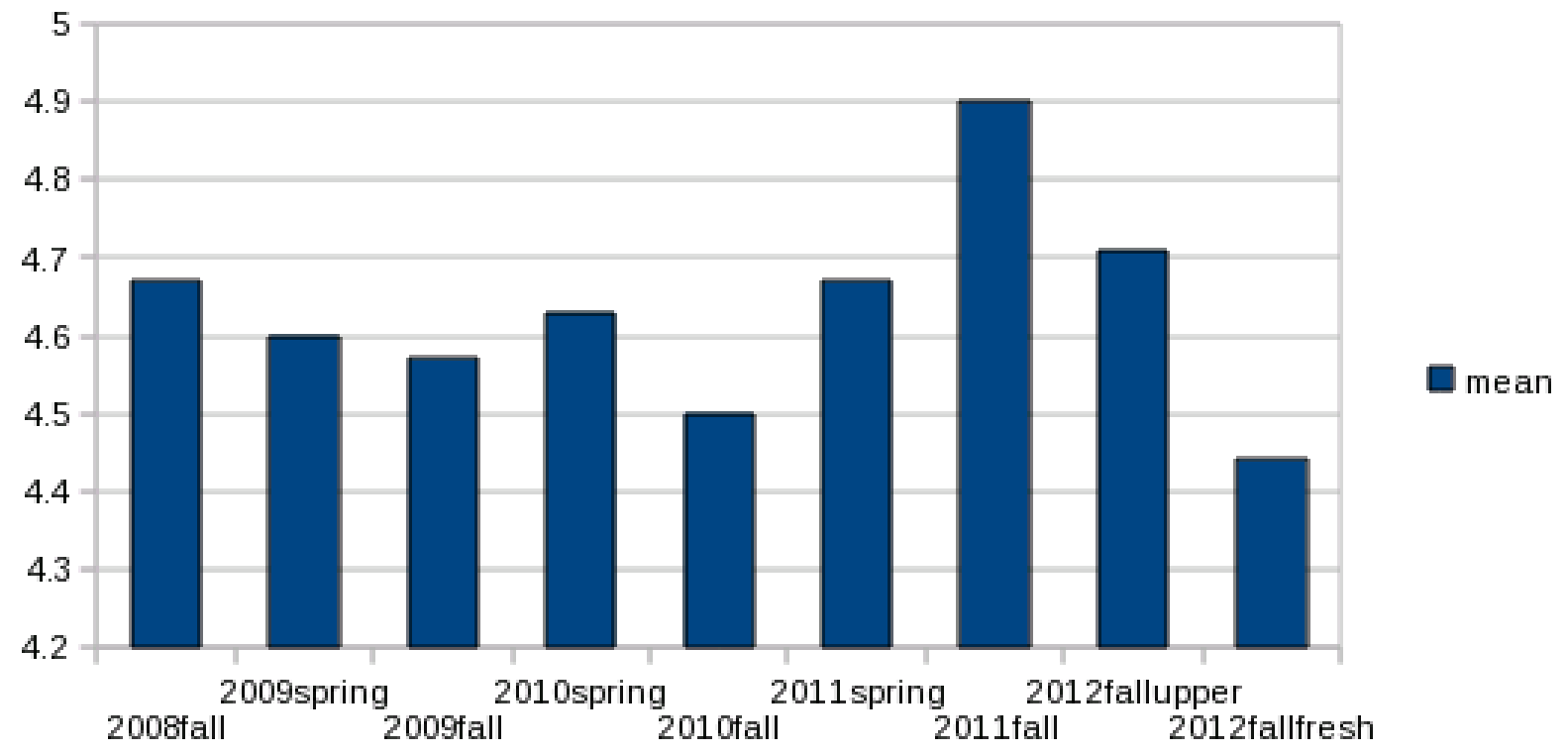

Student satisfaction with various aspects of the course is measured on a five-point scale, with 4 being superior and 5 being exceptional. Historically, student satisfaction with the course has ranked superior. In fall 2012, the upperclassmen continued to rank satisfaction at a mean of 4.7, second only to fall 2011. Freshmen had superior satisfaction, but were less satisfied than any past cohort. Detailed comparison of the fall 2012 upperclassmen and freshmen revealed that freshmen were slightly more dissatisfied with the ability to ask questions and get answers in class. This difference suggests freshmen are less comfortable in a large class setting, and may suggest freshmen had more difficulty absorbing content than upperclassmen. There was negligible difference between upperclassmen and freshmen on satisfaction with textbooks and resources.

Specific exercises have been designed over several semesters to assess ABET outcomes. This historical record allows retrospective analysis of the impact of delivery methodology on specific 
outcomes. All classes have met the specific measured outcomes for 2010-2012 with negligible difference among years. Interestingly, the same results are achieved for peer-reviewed presentation assessment and instructor-reviewed assessment.

Figure 7: Learning Outcome Assessment Example for Fall 2012

\begin{tabular}{|c|c|c|c|c|c|c|}
\hline $\begin{array}{l}\text { ABET } \\
\text { Outcomes }\end{array}$ & $\begin{array}{l}\text { Course } \\
\text { Objectives }\end{array}$ & $\begin{array}{l}\text { Specific } \\
\text { Goals of } \\
\text { the Course } \\
\text { Objectives }\end{array}$ & $\begin{array}{l}\text { Achievement } \\
\text { Criterion }\end{array}$ & $\begin{array}{l}\text { Observation } \\
\text { or evaluation } \\
\text { Mechanism }\end{array}$ & $\begin{array}{l}\text { Achieve } \\
\text { ment? } \\
\text { (Y/N) }\end{array}$ & $\begin{array}{l}\text { Evidence Collection } \\
\text { (must be accompanied } \\
\text { by this report) }\end{array}$ \\
\hline $\begin{array}{l}\text { Outcome } \\
\text { (a) }\end{array}$ & $\begin{array}{l}\text { Students } \\
\text { will have a } \\
\text { basic } \\
\text { knowledge } \\
\text { of the } \\
\text { Linux } \\
\text { operating } \\
\text { system } \\
\text { bash } \\
\text { command } \\
\text { shell. }\end{array}$ & $\begin{array}{l}\text { Students } \\
\text { complete a } \\
\text { certification } \\
\text {-like } \\
\text { assessment } \\
\text { to recall at } \\
\text { least 50 } \\
\text { basic Linux } \\
\text { commands }\end{array}$ & $\begin{array}{l}\text { Have an } \\
\text { examination } \\
\text { grade greater } \\
\text { than or equal to } \\
70 \% .\end{array}$ & $\begin{array}{l}\text { More than } \\
70 \% \text { of the } \\
\text { students } \\
\text { should achieve } \\
\text { this goal. }\end{array}$ & $\mathbf{Y}$ & $\begin{array}{l}28 \text { of } 30 \text { students } \\
\text { scored greater than } \\
70 \% \text { on the final exam . } \\
\text { Hence, } 93 \% \text { of the } \\
\text { students in the course } \\
\text { achieved this objective. }\end{array}$ \\
\hline $\begin{array}{l}\text { Outcome } \\
\text { (b) }\end{array}$ & $\begin{array}{l}\text { Use } \\
\text { analytical } \\
\text { thinking } \\
\text { skills to } \\
\text { evaluate } \\
\text { information } \\
\text { critically. }\end{array}$ & $\begin{array}{l}\text { Students } \\
\text { research a } \\
\text { current } \\
\text { Linux } \\
\text { distribution } \\
\text { topic and } \\
\text { prepare a } \\
\text { written } \\
\text { technical } \\
\text { report } \\
\text { according to } \\
\text { a report } \\
\text { rubric. }\end{array}$ & $\begin{array}{l}\text { Have an } \\
\text { assessment } \\
\text { grade greater } \\
\text { than or equal to } \\
70 \%\end{array}$ & $\begin{array}{l}\text { More than } \\
70 \% \text { of the } \\
\text { students } \\
\text { should achieve } \\
\text { this goal. }\end{array}$ & $\mathbf{Y}$ & $\begin{array}{l}29 \text { of } 30 \text { students } \\
\text { scored greater than } \\
70 \% \text { on the report } \\
\text { assessment. Hence, } \\
97 \% \text { of the students in } \\
\text { the course achieved this } \\
\text { objective. }\end{array}$ \\
\hline $\begin{array}{l}\text { Outcome } \\
\text { (g) }\end{array}$ & $\begin{array}{l}\text { Effectively } \\
\text { communica } \\
\text { te in } \\
\text { diverse } \\
\text { settings and } \\
\text { groups } \\
\text { using } \\
\text { written, } \\
\text { oral, and } \\
\text { visual } \\
\text { means. }\end{array}$ & $\begin{array}{l}\text { Students } \\
\text { will present } \\
\text { an } \\
\text { executive } \\
\text { summary } \\
\text { briefing of } \\
\text { their } \\
\text { research } \\
\text { paper for } \\
\text { peer } \\
\text { assessment } \\
\text { according to } \\
\text { the } \\
\text { presentation } \\
\text { rubric. }\end{array}$ & $\begin{array}{l}\text { The average } \\
\text { peer assessment } \\
\text { will be greater } \\
\text { than or equal to } \\
70 \% \text {. }\end{array}$ & $\begin{array}{l}\text { More than } \\
70 \% \text { of the } \\
\text { students } \\
\text { should achieve } \\
\text { this goal. }\end{array}$ & $\mathbf{Y}$ & $\begin{array}{l}25 \text { of } 30 \text { students } \\
\text { scored greater than } \\
70 \% \text { on the peer } \\
\text { assessment of the } \\
\text { presentation Hence, } \\
83 \% \text { of the students in } \\
\text { the course achieved this } \\
\text { objective. }\end{array}$ \\
\hline
\end{tabular}




\section{Discussion}

The course delivery approach described in this paper focused on a specific technology topic, the Linux operating system. The approach used - on-line textbook tailored to five-minute sessions, flashcards, multi-platform access, on-line peer review - is generally applicable to many other technology topics. Some examples of these other topics requiring specialized hardware and software installations include the study of computer operating systems, electronic circuit simulation, and computer forensics. However, the authors encountered limitations with this approach, and the same limitations affect other technology topics.

The authors did not employ a graphical user interface for this course. In the case of Linux instruction for scientific and enterprise system administration, emphasis is on the command line and remote management. Students used a single target Linux server for practice. At first, all students used a common login. This allowed all students to use exactly the same login procedure and execute exactly the same commands to gain familiarity with the operating system. Next, each student was assigned unique credentials on the same server, giving the students a multi-user environment not available if each student had their own physical or virtual machine. Students could interact with commands such as "wall”, "who", and "last” to emulate the experience of administering a large system.

The authors have provided students with individual virtual machines in other projects, allowing each student to have their own GUI desktop. In the case described, this approach was not practical for several reasons:

- The University does not have an operational cloud

- Students could use a free instance at Amazon Cloud, but sign-up requires a credit card

- The small format of smart phones makes a complete desktop very difficult to manipulate

- Off-campus access to University resources is blocked for remote desktop protocols, and the University does not have a cross-platform mobile device VPN client

- The thin-clients were already accessing a Windows image. Connecting directly to a Linux image would require re-booting the thin client image, which in turn would be administratively unmanageable in a classroom with back-to-back scheduling

- Accessing a Linux remote desktop through the Windows thin-client image is technically challenging, and with thirty images served by a single host, would have disappointing performance.

A challenge specific to Linux instruction is teaching the installation of the operating system.

- Obtaining the equivalent of a computer with no operating system installed, known as a "bare metal image", on a cloud is a somewhat specialized image request

- Interacting with the bare metal image requires use of some form of remote desktop or a tailored SSH connection

Installation was demonstrated using a loop-mounted bare metal image, but having 59 students with their own loop back image and tailored root access proved too large a challenge for fall 2012.

The thin client Windows images were not persistent, so adding plug-ins had to be repeated each class period. Modifying the image for all classes would have added unnecessary complexity to 
the general purpose image.

\section{Conclusion}

The authors described an approach to teaching a Linux operating system course using a completely generic classroom setting. No special equipment was required of students, and no additional expense was incurred by students. Quantitative measurement of student satisfaction metrics and learning outcomes verified that the approach achieved the same superior level of course satisfaction and learning achieved in past years using a dedicated classroom and lab.

The approach described contains several elements that are generally applicable to other engineering technologies. The lack of a graphical user interface currently prohibits the application of the approach to graphics-intensive instruction, such as computer-aided design drawing, integrated design environment-based computer-programming, and circuit simulation.

Use of the authors' approach can improve space utilization and reduce instructional cost without adverse impact to the quality of education.

The authors plan to apply this approach to an advanced Linux course in spring 2013 and expand the approach to an AC circuits course in fall 2013.

\section{References}

[1] “Proxmox - Proxmox VE.” [Online]. Available: http://www.proxmox.com/products/proxmox-ve. [Accessed: 28Mar-2013].

[2] L. Burton, S. Pope, I. Kareeb, C. Rhodes, R. Cobb,Jr., T. Graham, L.-S. Tsay, and C. Seay, “A College-Industry Partnership for Enterprise Computing,” Proceedings of the ASEE Annual Conference, San Antonio, Texas, Jun. 2012.

[3] R. Cobb,Jr., C. Rhodes, L. Burton, and J. Jones, “The Implications of Collaborative Instructional Environments on Teaching and Learning Stem Content to Economically Disadvantaged Learners: A Proof of Concept,"

EDULEARN12 4th International Conference on Education and New Learning Technologies,Barcelona,Spain, Jul. 2012.

[4] L. Burton, C. Hargrove, and C. BouSaba, "Mini-Clouds Enhance IT Education," The Third International Conference on the Virtual Computing Initiative, ICVCI3, Research Triangle Park, North Carolina, USA, Oct. 2009.

[5] R. Brown, "Integrate smart mobile devices into instruction.” [Online]. Available: http://it4educators.com/main/CoursesDetail.aspx?CourseId=1088. [Accessed: 28-Mar-2013].

[6] M. Qusay, "IEEE Xplore - Integrating mobile devices into the computer science curriculum," Frontiers in Education Conference, 2008. FIE 2008. 38th Annual, Oct. 2008.

[7] "connectbot - Secure shell (SSH) client for the Android platform - Google Project Hosting." [Online]. Available: http://code.google.com/p/connectbot/. [Accessed: 28-Mar-2013].

[8] T. Kausar, B. N. Choudhry, and A. A. Gujjar, "A comparative study to evaluate the effectiveness of computer assisted instruction (CAI) versus class room lecture (CRL) for computer science at ICS level,” The Turkish Online Journal of Educational Technology - TOJET, vol. 7, no. 4, p. 3, Oct. 2008.

[9] "FireSSH Add-ons for Firefox.” [Online]. Available: https://addons.mozilla.org/en-us/firefox/addon/firessh/. [Accessed: 28-Mar-2013].

[10] “EPUB Reader Add-on for Firefox.” [Online]. Available: https://addons.mozilla.org/enus/firefox/addon/epubreader/. [Accessed: 28-Mar-2013]. 